\title{
Pemberdayaan dan Peran Masyarakat Pesisir pada Pengembangan Mangrove menuju Ekowisata di Kabupaten Pamekasan
}

\author{
Endang Tri Wahyurini \\ Fakultas Pertanian, Universitas Islam Madura \\ Endangtriwahyurinis.pi rini@yahoo.co.id
}

\begin{abstract}
ABSTRAK
Tanaman mangrove mempunyai peranan yang sangat penting, yaitu sebagai penyangga kehidupan kawasan pantai. Mengembangkan tanaman mangrove bukan merupakan usaha yang mudah, hal ini memerlukan perhatian dan kepedulian dari semua pihak, baik masyarakat pesisir maupun pemerintah. Tujuan dari penelitian ini adalah untuk mengetahui bagaimana peranan pemerintah dalam pemberdayaan masyarakat pesisir dan peran masyarakat pesisir dalam pengembangan tanaman mangrove menuju "ekowisata" di Kabupaten Pamekasan. Metode penelitian dengan menggunakan deskriptif analitik, data primer diperoleh dari survei pada masyarakat petani mangrove yang bergabung pada LMDH (Lembaga Masyarakat Desa Hutan) (50 responden) yang aktif dan terlibat langsung dalam kegiatan pengembangan tanaman mangrove. Data data sekunder diambil dari dokumen yang relevan, adapun analisis data menggunakan deskriptif analitik. Hasil penelitian menunjukkan: (1) Peranan pemerintah terhadap pemberdayaan masyarakat pesisir dalam pengembangan tanaman mangrove memperoleh skor rata-rata 49,94 termasuk kategori cukup, (2) Partisipasi masyarakat dalam pengembangan tanaman mangrove memperoleh skor rata-rata 41,81 termasuk kategori cukup.
\end{abstract}

Kata kunci: Pemberdayaan, partisipasi, masyarakat pesisir, mangrove, ekowisata.

\section{Abstract}

Mangrove have the most important functions, like the pillar or life in shore are. The way to improve the mangrove are not easy as its look. It needs attention and affection from all the participants such as the Society of the shore and the goverment. The aim of this research is to know how the goverment position to manage the society so that the society can improve the mangroves to "Ecotourism" in Pamekasan. The researh methods are using analytics descriptive, primary documents form survey to the mangrove farmers that join LMDH (Lembaga Masyarakat Desa Hutan) (50 respondents) active and connect directly in all of the activities to improve the mangroves. The secondary documents is taken from the relevant documents, that the documents analyze is using analyticsdescriptive. The result of the survey showed (1) the goverments fuction in societies of the shore to improve the mangrove got the score 49,94 that include in enough categories. (2) the participants of the activities to improve the mangroves got score 41,81 that include in enough category.

Keywords : improvement, participation, shore society, mangroves and ecotourism. 


\section{PENDAHULUAN}

Luas seluruh wilayah Indonesia dengan jalur laut 12 mil adalah 5 juta $\mathrm{Km} 2$ terdiri dari luas daratan 1,9 km2, luas teritorial 0,3 juta $\mathrm{km} 2$, sedangkan luas perairannya 3,1 juta $62 \%$ dari seluruh wilayah Indonesia. Indonesia terdiri dari 17.508 pulau dan jumlah panjang garis pantainya sekitar $81.000 \mathrm{~km}$ (Nontji, 2005).

Wilayah pesisir dapat diartikan sebagai daerah peralihan antara ekosistem darat dan laut yang dipengaruhi oleh perubahan di darat dan laut (UU No. 27 Tahun 2007). Kondisi itu mempengaruhi produktifitas ekosistem di wilayah pantai. Hal ini yang menyebabkan wilayah pesisir menjadi salah satu andalan sumber perekonomian di Kabupaten Pamekasan.

Transisi antara daratan dan lautan di wilayah pesisir telah membentuk ekosistem yang beragam dan sangat produktif, serta memberikan nilai ekonomi yang luar biasa terhadap kehidupan manusia. Kemajuan sektor kelautan dan perikanan sangat tergantung pada bagaimana kebijakan pembangunan ekonomi yang dikembangkan (Apridar,2010)

Sejalan dengan pertambahan penduduk dan peningkatan kegiatan pembangunan sosial ekonomi, "nilai" wilayah pesisir terus bertambah. Konsekuensi dari tekanan terhadap pesisir ini adalah masalah pengelolaan yang timbul karena konflik pemanfaatan akibat berbagai kepentingan yang ada di wilayah pesisir (Nurmalasari, 2001) dalam Sutrisno (2015).

Wilayah pesisir pada dasarnya tersusun dari berbagai macam ekosistem (mangrove, terumbu karang, estuaria, pantai berpasir dan lainnya) yang satu sama lain saling berkait dan tidak berdiri sendiri. Perubahan atau kerusakan yang menimpa satu ekosistem akan menimpa ekosistem lainnya. Selain itu wilayah pesisir juga dipengaruhi oleh berbagai macam kegiatan manusia maupun proses-proses alamiah yang terdapat di lahan atas (upland areas) maupun laut lepas (oceans). Kondisi empiris semacam ini mensyaratkan dalam melakukan pengelolaan pesisir dan lautan harus memperhatikan

Pembangunan kelautan hendaknya diarahkan untuk meraih empat tujuan secara seimbang. Pertama pertumbuhan ekonomi tinggi secara berkelanjutan, kedua, peningkatan kesejahteraan seluruh pelaku usaha (para nelayan), ke tiga, pembudidaya ikan dan masyarakat kelautan lainnya yang berskala kecil, terpeliharanya kelestarian lingkungan dan sumberdaya kelautan, ke empat, menjadikan laut sebagai pemersatu dan tegaknya kedaulatan bangsa. (Apridar,2010).

Berdasarkan hal tersebut maka pemerintah Kabupaten Pamekasan berencana membuat "Ekowisata" dikawasan hutan mangrove. Dengan berdirinya ekowisata diharapkan masyarakat luas bisa memanfaatkan keberadaan ekosistem hutan mangrove beserta kekayaaan yang tersimpan didalamnya. Di kawasan "Ekowisata" bisa dimanfaatkan sebagai tempat penelitian, 
pendidikan, kawasan konservasi dan tempat rekreasi. Oleh karena itu perlu dilakukan pembangunan kawasan pesisir dengan optimal dan terpadu(Ummah \& Wajdi, 2016).

Keadaan kawasan pantai dan laut di Indonesia masih sangat memprihatinkan hal ini akibat dari rusaknya beberapa sumberdaya alam hayati pesisir seperti hutan mangrove. Demikian juga kondisi hutan mangrove di sepanjang pantai Kabupaten Pamekasan. Berdasarkan data Dinas Kehutanan dan Perkebunan Kabupaten Pamekasan (2003a) menunjukkan bahwa luas hutan mangrove di Kabupaten Pamekasan sejumlah 720 ha dan sekitar 200 ha dalam kondisi rusak.

Untuk mengurangi dampak yang lebih besar lagi terhadap tekanan sumber daya mangrove, diperlukan pemberdayaan masyarakat pesisir yang dilakukan secara intensif sehingga dapat menjadikan masyarakat sebagai komponen utama penggerak partisipasif dalam pengembangan tanaman mangrove. Begitu pula sebaliknya rendahnya pemahaman masyarakat terhadap fungsi dan peranan tanaman mangrove dapat menyebabkan makin menurunnya daya dukung lingkungan sumberdaya pesisir dan kualitas hidup komunitas penduduk setempat.

Kusmana (1995) dalam Sutrisno (2015) menyatakan bahwa fungsi hutan mangrove dibagi atas tiga yaitu: (1) fungsi fisik, dapat melindungi lingkungan dari pengaruh oseanografi (pasang surut, arus, angin topan, dan gelombang), mengendalikan abrasi dan mencegah intruisi air laut ke darat; (2) fungsi biologi, sangat berkaitan dengan perikanan yaitu sebagai daerah asuhan (nursery ground), daerah mencari makan (feeding ground), dan daerah pemijahan (spawning ground) dari beberapa jenis ikan dan udang, serta merupakan penyuplai unsur-unsur hara utama di pantai khususnya daerah lamun dan terumbu karang;(3) fungsi ekonomi, sebagai sumber kayu kelas satu, bubur kayu, bahan kertas, chips, dan arang(Wajdi, 2016).

Peran pemerintah dan masyarakat sangat mempengaruhi faktor keberhasilan rencana membuat kawasan "Ekowisata" di Kabupaten Pamekasan. Upaya pelestarian mangrove harus selalu dilakukan hal ini untuk. Perlu dilakukan perhatian dan kerjasama antara pemerintah dan masyarakat dalam upaya pelestarian ini. Kurangnya pemahaman masyarakat pesisir terhadap manfaat mengusahakan tanaman mangrove harus segera diperbaiki. Kurangnya pemahaman bahwa mangrove bermanfaat untuk kegiatan usaha yang mempunyai dampak secara langsung dalam memenuhi kebutuhan hidup seperti pengolahan hasil perikanan, pertambakan, pertanian dan kurang memperhatikan pengelolaan tanaman mangrove berkelanjutan sehingga tanaman mangrove yang ada tidak diperhatikan pertumbuhannya.

Berdasarkan latar belakang tersebut, rumusan masalah dalam penelitian ini adalah bagaimana upaya pemerintah dalam pemberdayaan masyarakat pesisir dan bagaimana partisipasi 
masyarakat pesisir dalam pengembangan tanaman mangrove di Kabupaten Pamekasan dalamuapaya menuju kawasan Ekowisata. Sedangkan tujuan penelitian ini adalah untuk mengetahui upaya pemerintah dalam pemberdayaan masyarakat pesisir dan partisipasi masyarakat pesisir dalam pengembangan tanaman mangrove menuju Ekowisata di Kabupaten Pamekasan.

\section{METODE}

Lokasi penelitian dilaksanakan di Desa Lembung Kecamatan Galis Kabupaten Pamekasan dengan pertimbangan bahwa wilayah tersebut merupakan wilayah pesisir yang merupakan tempat pengembangan tanaman mangrove yang direncanakan sebagai kawasan "Ekowisata". Waktu penelitian dilaksanakan pada bulan Pebruari sampai dengan bulan November 2016.

Metode dalam penelitian ini menggunakan metode deskriptif. Metode deskriptif bertujuan untuk membuat deskripsi, gambaran atau lukisan secara sistematis, faktual dan akurat mengenahi fakta-fakta, sifat-sifat serta hubungan antar fenomena yang diselidiki. Jumlah sampel ditentukan berdasarkan besarnya jumlah petani mangrove yang terlibat langsung dalam aktivitas pengembangan tanaman mangrove di Desa Lembung Kecamatan Galis Kabupaten Pamekasan yang memenuhi penstrataan dengan tingkat kesalahan $5 \%$ (Nasir ,2003). Formulasi untuk menentukan sampel dalam penelitian ini yaitu dengan menggunakan purposive sampling yaitu menentukan sampel yang akan diteliti yaitu seluruh anggota LMDH Sabuk Hijau yang berperan langsung dalam kegiatan pengembangan tanaman mangrove.

Analisis deskriptif yang digunakan adalah penyajian tabel dan grafik yang digunakan seperti Custom table, distribusi frekuensi (Santoso, 2003), selain itu juga untuk memberi gambaran profil dan sampel yang bermanfaat untuk mendeskripsikan variabel pemberdayaan masyarakat pesisir dan partisipasi masyarakat pesisir dalam pengembangan tanaman mangrove di Kabupaten Pamekasan dengan menggunakan skor jawaban. Untuk mengtahui secara tepat tingkat persentase skor jawaban digunakan rumus sebagai berikut:

$$
\%=\mathrm{n} / \mathrm{N}=100 \%
$$

Keterangan: $\mathrm{n}=$ nilai yang diperoleh, $\mathrm{N}=$ jumlah responden, $\%=$ persentase. (Suharsimi, 2006)

Untuk mengetahui distribusi masing-masing variabel yang pengumpulannya dengan menggunakan angket, setiap indikator dari data yang telah dikumpulkan terlebih dahulu diklasifikasikan dan kemudian diberi skor. Dalam menentukan penskoran untuk masing-masing indikator dari variabel pemberdayaan masyarakat pesisir berdasarkan pada kuisioner yang sudah dipersiapkan.

Penentukan kategori deskripsi persentase dengan jumlah item pertanyaan 20, maka diperoleh skor maksimal: $20 \times 5=100$ dan skor minimal: $20 \times 1=20$. Selanjutnya dibuat tabel 
kategori yang disusun dengan perhitungan sebagai berikut: (a) Menetapkan skor tertinggi: 90, (b) Menetapkan skor terendah: 20, (c) Menetapkan rentang skor. Rentang diperoleh dengan cara mengurangi skor tertinggi dengan skor terendah sehingga diperoleh: 90-20 $=70$. Interval kelas diperoleh dengan cara membagi rentang dengan panjang kriteria, sehingga diperoleh: 70:5 =14. Kriteria interval untuk pemberdayaan masyarakat pesisir dapat dibuat sebagaimana Tabel 1. Sedangkan dalam menentukan skor untuk masing- masing indikator dari variabel partisipasi masyarakat pesisir, perlakuannya sama dan dimodifikasi sesuai dengan jumlah item kuisioner.

\section{HASIL DAN PEMBAHASAN}

\section{Identitas responden}

Responden dalam penelitian ini adalah sebanyak 50 petani yang tergabung dalam Lembaga Masyarakat Desa Hutan (LMDH) Sabuk Hijau kawasan pesisir dan terlibat langsung dalam pengembangan tanaman mangrove. Identitas responden secara rinci dapat dilihat pada Tabel 2.Tabel 2 terlihat bahwa umur responden paling banyak berkisar 40-50 tahun (37,37\% disusul umur 31-40 (24,91\%), hal ini menunjukkan pada kisaran umur 31-50

Pendidikan responden sebagian besar tingkat SMA (47,69\%), kemudian disusul pendidikan SMP $(23,84 \%)$, hal ini diduga yang berpendidikan setingkat SMA merupakan generasi muda, sementara yang berpendidikan setingkat SD adalah generasi tua. Dilihat dari pendidikannya, mereka sudah cukup untuk didorong untuk mengetahui pentingnya pengelolaan hutan mangrove. Pekerjaan responden sebagian besar adalah petani yang mencapai 51,60 \%, hal ini wajar karena masyarakat yang tinggal dikawasan pesisir pada kegiatan dipantai sebagai pencari dan pengolah lorjuk, petani garam maupun petambak bandeng/udang dan nelayan. Oleh karena itu sangatlah wajar kalau mereka sangat peduli terhadap kelestarian pantai dan berusaha untuk berpartisipasi dalam pengembangan tanaman mangrove yang berada di wilayahnya.

\section{Wilayah Pesisir dan Tanaman Mangrove}

Program pengelolaan wilayah pesisir yang telah diimplementasikan mengenai batas suatu wilayah pesisir di beberapa negara antara lain: pertama, batas wilayah pesisir kearah darat pada umumnya adalah jarak secara arbitrer dari rata-rata pasut tinggi (Mean High Tide) dan batas arah laut umumnya adalah sesuai dengan batas jurisdiksi provinsi. Hal ini sesuai dengan UU No. 27 Tahun 2007 Pasal 50 ayat 2 dan 3, bahwa Gubernur berwenang memberikan Hak Pengusahaan Perairan Pesisir (HP-3) di wilayah perairan pesisir sampai dengan 12 mil laut diukur dari garis pantai kearah laut lepas dan/atau kearah perairan kepulauan, dan perairan lintas kabupaten/kota. Dan BuPamekasan/Walikota berwenang memberikan HP-3 wilayah perairan pesisir kepada 1/3 dari wilayah kewenangan provinsi. Sementara Perda Kabupaten Pamekasan No. 4 Tahun 2003, 


\section{ENGAGEMENT}

Jurnal Pengabdian Kepada Masyarakat

ISSN : 2579-8375 (Print)

ISSN : 2579-8391 (Online)
This work is licensed under a Creative Commons

Attribution-ShareAlike 4.0 International License.

CC BY SA

Pasal 5 ayat 1, menyatakan bahwa Pemerintah Daerah menetapkan kebijaksanaan pengelolaan wilayah pesisir dan laut berdasarkan peraturan perundang-undangan yang berlaku.

Tabel 1. Pengukuran Skala Likert pada Pemberdayaan Masyarakat Pesisir

\begin{tabular}{|l|l|l|}
\hline No & Interval persentase & Kriteria \\
\hline 1 & $30-40$ & Sangat rendah \\
\hline 2 & $41-50$ & Rendah \\
\hline 3 & $51-60$ & Cukup \\
\hline 4 & $61-70$ & Tinggi \\
\hline 5 & $71-90$ & Sangat tinggi \\
\hline
\end{tabular}

Tabel 2. Identitas Responden

\begin{tabular}{|c|c|c|c|}
\hline No & Uraian & Frekuensi & $\%$ \\
\hline \multirow[t]{7}{*}{1} & Umur & & \\
\hline & $20-30$ & 22 & 7,80 \\
\hline & $31-40$ & 71 & 25,18 \\
\hline & $41-50$ & 105 & 37,23 \\
\hline & $51-60$ & 64 & 22,70 \\
\hline & $>60$ & 20 & 7,09 \\
\hline & Jumlah & 282 & 100 \\
\hline \multirow[t]{7}{*}{2} & Pendidikan & & \\
\hline & Tidak sekolah & 6 & 2,13 \\
\hline & SD & 67 & 23,76 \\
\hline & SMP & 51 & 18,08 \\
\hline & SMA & 134 & 47,52 \\
\hline & D3/S1 & 24 & 8,51 \\
\hline & Jumlah & 282 & 100 \\
\hline \multirow[t]{6}{*}{3} & Pekerjaan & & \\
\hline & Tani & 145 & 51,60 \\
\hline & Nelayan & 18 & 6,41 \\
\hline & Wiraswasta & 39 & 13,88 \\
\hline & PNS & 1 & 0,36 \\
\hline & Perangkat desa & 69 & 24,56 \\
\hline
\end{tabular}

Volume 1, Number 1, Mei 2017 | 54

Pemberdayaan dan Peran Masyarakat Pesisir pada Pengembangan Mangrove Menuju Ekowisata di 


\begin{tabular}{|l|l|l|l|}
\hline & Lain-lain & 10 & 3,56 \\
\hline & Jumlah & 282 & 100,00 \\
\hline & & & \\
\hline
\end{tabular}

Data Primer diolah (2016)

Lahan sawah di wilayah pesisir seluas $50 \mathrm{Ha}$ Kabupaten Pamekasan, dan luas tambak 70 Ha dan luas tanah kosong potensial seluas 70 ha (Dinas Kehutanan dan Perkebunan Pamekasan ,2003). Tambak seluas tersebut merupakan potensi ekonomi yang sangat menjanjikan untuk dikembangkan lebih lanjut dengan mengoptimalkan potensi tambak yang sekarang ada. Pemanfaatan tambak menurut responden dikelola dengan dua cara yaitu sebagai tambak garam dan sebagai tambak budidaya terutama budidaya bandeng dan udang. Yang membudidayakan udang dilakukan secara intensif tetapi jumlahnya cukup banyak. Selain itu terdapat juga masyarakat pencari lorjuk yaitu sejenis kerang yang memiliki keunikan tersendiri. Harga lorjuk ini cukup mahal jika dibandingkan dengan komoditas lainnya.

Pada musim kemarau yaitu sekitar bulan Juli sampai September tambak dikelola dengan usaha tambak garam dan menurut responden tambak garam ini lebih menguntungkan jika dibanding dengan budidaya bandeng maupun udang. Sutrisno (2013) potensi lahan tambak garam dikawasan pesisir memiliki kekuatan untuk usaha garam yang baik dan menguntungkan, mengingat kebutuhan garam dalam negeri belum tercukupi dan untuk mencukupi kebutuhan garam tersebut masih mengimpor. Kondisi ini merupakan prospek yang perlu dimanfaatkan oleh para petambak garam termasuk petambak garam di Kabupaten Pamekasan.

Tanaman bakau (mangrove) adalah ekosistem yang berupa hamparan lahan pantai yang berisi sumberdaya alam hayati dengan kekhasan atau ciri khas hidup di wilayah pantai. Wilayah pantai berhutan bakau (mangrove) berfungsi memberi perlindungan kepada perikehidupan pantai dan lautan .

Tanaman mangrove dan ekosistem mangrove cukup tahan terhadap berbagai gangguan dan tekanan lingkungan. Namun demikian mangrove tersebut sangat peka terhadap pengendapan atau sedimentasi, tinggi rata-rata permukaan air, pencucian serta tumpahan minyak. Keadaan ini mengakibatkan penurunan kadar oksigen dengan cepat untuk kebutuhan respirasi dan pada akhirnya dapat menyebabkan kematian mangrove. Perubahan faktor-faktor yang mengontrol pola salinitas substrat dapat menyebabkan perubahan komposisi spesies, dan salinitas yang lebih dari 90 ppm dapat mengakibatkan kematian biota dalam jumlah besar. Perubahan salinitas dapat diakibatkan oleh perubahan siklus hidrologi, aliran air tawar dan pencucian terus menerus seperti kegiatan pengerukan. (Sutrisno,2015) 
Kerusakan tanaman mangrove ini berakibat menurunnya produktivitas tambak, karena tanaman mangrove berfungsi sebagai tempat pemijahan, tempat pengasuhan dan tempat makanan bagi biota laut termasuk ikan, udang, dan kepiting. Peran utama masyarakat pesisir dalam pengelolaan tanaman mangrove sangat menentukan keberhasilan kelestarian wilayah mangrove. Ditegaskan pula bahwa masyarakat yang tergabung dalam kelembagaan baik secara lokal, regional maupun nasional akan lebih mendorong terciptanya wilayah tanaman mangrove.

\section{Pemberdayaan Masyarakat}

Rasyid (1996) menyatakan bahwa pemberdayaan merupakan tugas pokok dari pemerintah, disamping dua tugas lainnya yakni pelayanan/service dan pengaturan/regulatory. Tugas pemberdayaan pada hakikatnya diarahkan pada terwujudnya sebuah komunitas masyarakat yang berdaya dan mandiri yang mampu berperan sebagai mitra dari pemerintah dalam pembangunan. Dengan pengertian lain, yaitu sebuah masyarakat yang mampu berperan sebagai subyek dalam pembangunan, tidak sebagai obyek dari pembangunan seperti yang telah terjadi selama ini. Pemberdayaan masyarakat bukan membuat masyarakat menjadi makin tergantung pada berbagai program pemberian (charity). Pendekatan utama dalam konsep pemberdayaan adalah bahwa masyarakat tidak dijadikan obyek dari berbagai proyek pembangunan tetapi merupakan subyek dari upaya pembangunannya sendiri (Sumodiningrat, 1999). Sementara itu pemberdayaan masyarakat pesisir ditujukan untuk masyarakat diwilayah pesisir dalam pengembangan tanaman mangrove di Kabupaten Pamekasan.

Hasil penelitian menunjukkan bahwa peranan pemerintah terhadap pemberdayaan masyarakat pesisir dalam pengembangan tanaman mangrove di Kabupaten Pamekasan dievaluasi dengan menggunakan variasi nilai yang terbagi dalam 5 (lima) kategori dengan interval nilai yaitu: sangat rendah $(20,00-30,00)$, rendah (30,01-40,00), cukup (40,01-50,00), tinggi $(50,01-60,00)$, dan sangat tinggi $(60,01-70,00)$. Sedangkan untuk indikator penyuluhan, sosialisasi, pembinaan dan studi banding dievaluasi dengan menggunakan variasi nilai yang terbagi dalam 5 (lima) kategori dengan beberapa modifikasi. Hasil analisis peran pemerintah terhadap pemberdayaan masyarakat pesisir dalam pengembangan tanaman mangrove di Kabupaten Pamekasan secara rinci dapat dilihat pada Tabel 4. Tabel 4 tersebut menunjukkan bahwa skor rata-rata dari semua indikator dan variabel pemberdayaan masyarakat pesisir:

Pertama, penyuluhan memperoleh skor 17,34 termasuk katagori tinggi, artinya peran pemerintah dalam penyuluhan berkaitan dengan pengembangan tanaman mangrove sudah dianggap baik dan efektif sehingga masyarakat pesisir diharapkan dapat mengembangkan tanaman mangrove untuk menjaga kelestarian pantai. Hal ini sesuai dengan pendapat 
Kartasaputra (1994) bahwa tujuan penyuluhan jangka pendek untuk menumbuhkan perubahanperubahan yang lebih terarah dalam aktivitas usahatani dipedesaan, perubahan-perubahan mana hendaknya menyangkut: tingkat pengetahuan, kecakapan atau kemampuan sikap dan motif tindakan petani. Namun demikian masih ada 9,22\% masyarakat pesisir yang masuk katagori sangat rendah, hal ini juga wajar karena diduga mereka kurang interaktif dengan masyarakat lain atau berpandangan lain bahwa urusan kelestarian pantai adalah urusan pemerintah, sehingga mereka tidak perlu "repot-repot" ikut terlibat didalamnya. Mestinya pendapat seperti itu tidak perlu terjadi karena lingkungan pantai sebagai salah satu kesatuan kegiatan ekonomi adalah milik bersama yang harus dikelola dan dijaga bersama.

Kedua, peran pemerintah dalam sosialisasi tentang pengembangan tanaman mangrove termasuk katagori cukup dengan skor 11,82, hal ini menunjukkan pemerintah masih perlu terus menerus mengadakan sosialisasi, seperti pemasangan spanduk, baliho, papan peringatan, pertemuan melalui RT/RW disertai dengan tindakan dan bantuan berupa bibit mangrove agar masyarakat pesisir dapat tertarik dan melaksanakan anjuran dalam sosialisasi tersebut. Terdapat $28,37 \%$ responden masuk dalam katagori tinggi, artinya mereka sudah menyadari bahwa peran pemerintah dalam sosialisasi sudah dianggap cukup baik oleh karena itu perlu dorongan untuk implementasinya. Sementara itu masih terdapat 12,06 \% responden yang termasuk katagori rendah, hal ini diduga mereka masih aPamekasans terhadap pengembangan tanaman mangrove untuk kelestarian pantai, mereka beranggapan bahwa semua itu adalah urusan pemerintah, oleh karena itu sosialisasi pengembangan tanaman mangrove perlu diintensifkan agar mereka tumbuh kesadarannya mengingat kelestarian pantai itu penting. Hasil ini sesuai dengan penelitian (Supriyanto, 2004) yang menyatakan bahwa kegiatan sosialisasi sebagai upaya peningkatan pengetahuan dianggap sebagai suatu keharusan yang perlu diikuti semua masyarakat ditengah menurunnya sumberdaya perikanan tangkap akibat rusaknya ekosistem payau berupa tanaman mangrove.

Ketiga, peran pemerintah dalam pembinaan tentang pengembangan tanaman mangrove hubungannya dengan kelestarian pantai termasuk dalam katagori tinggi dengan skor 14,67. Artinya pembinaan yang dilakukan oleh pemerintah melalui dinas/instansi terkait sudah cukup efektif dan perlu konsistensi implementasi program serta pembinaan dalam pengembangan tanaman mangrove. Senada hasil penelitian Supriyanto (2004), masyarakat menganggap pembinaan yang dilakukan dinas/instansi terkait bermanfaat secara langsung dan ditindaklanjuti dengan kegiatan fisik dilapangan seperti: rehabilitasi lahan tambak yang rusak berikut bibit pohon dan benih ikan, pakan dan batuan pemeliharaan. Masih terdapat 6,38 \% responden masuk dalam 


\section{ENGAGEMENT}

Jurnal Pengabdian Kepada Masyarakat

ISSN : 2579-8375 (Print)

ISSN : 2579-8391 (Online)
This work is licensed under a Creative Commons

Attribution-ShareAlike 4.0 International License.

CC BY SA

katagori sangat rendah dalam menerima pembinaan, hal ini perlu mendapatkan perhatian lebih agar mereka dapat menerima dengan baik dalam pembinaan pengembangan tanaman mangrove untuk kelestarian pantai.

Tabel 4. Pemberdayaan Masyarakat Pesisir

\begin{tabular}{|c|c|c|c|c|c|}
\hline $\begin{array}{l}\text { Indikator dan } \\
\text { Variabel }\end{array}$ & Interval & Kriteria & Frekuensi & $\%$ & Skor \\
\hline \multirow[t]{6}{*}{ Penyuluhan } & $07,00-10,40$ & Sangat rendah & 26 & 9,22 & \\
\hline & $10,41-13,80$ & Rendah & 14 & 4,96 & \\
\hline & $13,81-17,20$ & Cukup & 70 & 24,82 & $4.889 / 282=$ \\
\hline & $17,21-20,60$ & Tinggi & 145 & 51,42 & 17,34 \\
\hline & $20,61-24,00$ & Sangat tinggi & 27 & 9,57 & \\
\hline & & Jumlah & 282 & 100,00 & \\
\hline \multirow[t]{6}{*}{ Sosialisasi } & $06,00-08,60$ & Sangat rendah & 34 & 12,06 & \\
\hline & $08,69-11,20$ & Rendah & 91 & 32,27 & $3.332 / 282=$ \\
\hline & $11,21-13,88$ & Cukup & 67 & 23,76 & 11,82 \\
\hline & $13,89-16,40$ & Tinggi & 80 & 28,37 & \\
\hline & $16,41-19,00$ & Sangat tinggi & 10 & 3,55 & \\
\hline & & Jumlah & 282 & 100,00 & \\
\hline \multirow[t]{6}{*}{ Pembinaan } & $06,00-8,60$ & Sangat rendah & 18 & 6,38 & \\
\hline & $08,69-11,20$ & Rendah & 14 & 4,96 & \\
\hline & $11,21-13,80$ & Cukup & 31 & 10,99 & $4.136 / 282=$ \\
\hline & $13,81-16,40$ & Tinggi & 181 & 64,18 & 14,67 \\
\hline & $16,41-19,00$ & Sangat tinggi & 38 & 13,48 & \\
\hline & & Jumlah & 282 & 100,00 & \\
\hline Pemberdayaan & $20,00-30,00$ & Sangat rendah & 13 & 4,61 & \\
\hline Masyarakat & $30,01-40,00$ & Rendah & 24 & 8,51 & $14.082 / 282=$ \\
\hline
\end{tabular}




\begin{tabular}{|l|l|l|l|l|l|}
\hline Pesisir & $40,01-50,00$ & Cukup & 99 & 35,11 & 49,94 \\
\hline & $50,01-60,00$ & Tinggi & 120 & 42,55 & \\
\hline & $60,01-70,00$ & Sangat tinggi & 26 & 9,22 & \\
\hline & & Jumlah & 282 & 100,00 & \\
\hline & & & & & \\
\hline
\end{tabular}

Sumber : Data primer (2016)

Keempat, pemberdayaan masyarakat pesisir yang dilakukan oleh pemerintah melalui penyuluhan, sosialisasi, pembinaan dan studibanding termasuk dalam katagori cukup baik dengan skor 49,94. Hal ini masih perlu ditingkatkan pemberdayaannya, mengingat betapa penting pengembangan tanaman mangrove untuk kelestarian pantai. Namun demikian ada 42,55\% responden masuk dalam katagori tinggi sehingga mereka perlu didorong untuk mengembangkan tanaman mangrove. Penelitian Parawansa (2007) dalam Sutrisno (2015) memperkuat penelitian ini bahwa prioritas kebijakan pengelolaan hutan mangrove Teluk Jakarta secara berkelanjutan berdasarkan aspirasi stakeholders secara berturut-turut adalah pemberdayaan masyarakat, penerapan teknologi dan pengelolaan terpadu.

\section{Partisipasi Masyarakat}

Mulyana (1996) menyatakan bahwa partisipasi/peran serta masyarakat dapat didefinisikan: (1) adanya subyek yang berinteraksi yaitu individu yang berada dalam suatu unit masyarakat (kelompok), organisasi perekonomian, pemerintah dan bangsa. Masing-masing memiliki keleluasaan untuk mengambil keputusan sendiri- sendiri tetapi terikat dalam suatu ikatan solidaritas tertentu untuk mewujudkan kepentingan atau rencana bersama; (2) adanya kerelaan dan kesadaran dari individu untuk menjalankan peran yang diberikan oleh kelompok secara iklas. Keikutsertaan tidak atas dasar kekuasaan pemimpin (formal); dan (3) partisipasi berkonotasi kepada keterlibatan anggota perorangan dalam proses pengelolaan suatu kegiatan (pengambilan keputusan bersama, pengarahan, sumberdaya, pengawasan dan penyesuaian).

Hasil penelitian terhadap partisipasi masyarakat pesisir dalam pengembangan tanaman mangrove di Kabupaten Pamekasan terdiri dari 4 indikator yaitu perencanaan, pembibitan, penanaman, dan pemeliharaan. Variabel partisipasi masyarakat dievaluasi dengan menggunakan variasi nilai yang terbagi dalam 5 (lima) katagori yaitu: sangat rendah (15 - 24), rendah (25 - 33), cukup (34 - 42), tinggi (43 - 51), dan sangat tinggi (52 - 60). Sementara itu untuk indikator perencanaan, pembibitan, penanaman, dan pemeliharaan dievaluasi dengan menggunakan variasi nilai yang terbagi dalam 5 (lima) katagori dengan beberapa modivikasi. Hasil analisis partisipasi masyarakat pesisir dalam pengembangan tanaman mangrove di Kabupaten Pamekasan secara 
rinci dapat dilihat pada Tabel 5. Dapat dilihat pada Tabel 5 bahwa skor rata- rata dari semua indikator dan variabel partisipasi masyarakat pesisir:

Pertama, proses perencanaan masih perlu meningkatkan partisipasi masyarakat pesisir agar mereka merasa terlibat dalam perencanaan pengembangan tanaman mangrove, memperoleh skor rata-rata 13,41 termasuk katagori cukup. Namun demikian terdapat 51,06 \% responden masuk dalam katagori tinggi, artinya proses perencanaan sebagian besar melibatkan partisipasi masyarakat pesisir karena dalam pengembangan selanjutnya peranan mereka sangat besar sehingga partisipasinya perlu dilibatkan dalam proses perencanaan pengembangan tanaman mangrove. Hasil penelitian yang lain menunjukkan bahwa proses perencanaan yang baik perlu melibatkan masyarakat yang menerima dampak secara langsung. UU No 25/2004, perencanaan adalah suatu proses untuk menentukan tindakan masa depan yang tepat, melalui urutan pilihan, dengan memperhitungkan sumber daya yang tersedia. Perencanaan, dapat memberikan tuntunan bagi pencapaian tujuan organisasi yang telah ditetapkan menjadi lebih efisien dan efektif, karena perencanaan meliputi keputusan tentang waktu yang akan datang, apa yang akan dilakukan, bila akan dilakukan, dan siapa yang akan melakukan.

Kedua, partisipasi masyarakat pesisir dalam pembibitan mangrove memperoleh skor ratarata 10,67 termasuk katagori cukup. Artinya partisipasi masyarakat pesisir adalah cukup baik dan peduli terhadap pembibitan mangrove, karena mereka menganggap pembibitan mangrove adalah salah satu kegiatan untuk pengembangan tanaman mangrove yang mempunyai manfaat besar terhadap pelestarian pantai sehingga masyarakat pesisir merasa peduli terhadap kegiatan yang satu ini. Terdapat 8,87 \% responden yang masih sangat rendah kepeduliannya/partisipasinya terhadap pembibitan mangrove, hal ini diduga mereka masih merasa aPamekasans karena menganggap pembibitan mangrove merupakan tugas pemerintah untuk menyediakan. Pendapat seperti itu sebenarnya tidak perlu terjadi, oleh karena itu peranan penyuluhan dan sosialisasi yang gencar dan efektif perlu dilakukan agar mereka mengetahui dan tertarik betapa pentingnya pengembangan tanaman mangrove dalam peletarian pantai.

Ketiga, partisipasi masyarakat pesisir dalam penanaman mangrove sudah cukup baik dengan skor rata-rata 8,94. Menurut mereka bibit yang sudah tersedia baik oleh swadaya masyarakat maupun bantuan pemerintah atau bantuan swasta, perlu segera ditanam sesuai perencanaan dan baku teknis penanaman sehingga pengembangan tanaman mangrove dalam rangka pelestarian pantai dapat berjalan dengan baik. Partisipasi masyarakat pesisir dalam penanaman mangrove yang mengacu pada teknis penanaman dari hasil penyuluhan dan sosialisasi dibawah bimbingan dinas/instansi terkait dan penyuluh menjadikan mereka antusias 


\section{ENGAGEMENT}

Jurnal Pengabdian Kepada Masyarakat

ISSN : 2579-8375 (Print)

ISSN : 2579-8391 (Online)
This work is licensed under a Creative Commons

Attribution-ShareAlike 4.0 International License.

CC BY SA

untuk terlibat dalam penanaman. Namun demikian masih ada 9,93\% responden sangat rendah partisipasinya terhadap penanaman mangrove, hal ini perlu diantisipasi dengan pendekatan penyuluhan dan sosialisasi yang gencar dan terus menerus agar mereka mau merubah sikapnya untuk berpartisipasi dalam penanaman mangrove.

Tabel 5. Partisipasi Masyarakat Pesisir

\begin{tabular}{|c|c|c|c|c|c|c|}
\hline $\begin{array}{l}\text { Sub variabel } \\
\text { dan variabel }\end{array}$ & Interval & Kriteria & Frekuensi & Persentase & $\begin{array}{l}\text { Skor rata- } \\
\text { rata }\end{array}$ & \\
\hline & $6,0-8,6$ & $\begin{array}{l}\text { Sangat } \\
\text { rendah }\end{array}$ & 34 & 12,06 & & \\
\hline Sub variabel & $8,7-11,2$ & Rendah & 32 & 11,35 & $3782 / 282=$ & \\
\hline \multirow[t]{4}{*}{ Perencanaan } & $11,3-13,8$ & Cukup & 55 & 19,50 & 13,41 & \\
\hline & $13,9-16,4$ & Tinggi & 144 & 51,06 & & \\
\hline & $16,5-19,0$ & $\begin{array}{l}\text { Sangat } \\
\text { tinggi }\end{array}$ & 17 & 6,03 & & \\
\hline & & Jumlah & 282 & 100 & & \\
\hline Sub variabel & $5,0-6,8$ & $\begin{array}{l}\text { Sangat } \\
\text { rendah }\end{array}$ & 25 & 8,87 & & \\
\hline \multirow[t]{5}{*}{ Pembibitan } & $6,9-8,6$ & Rendah & 40 & 14,18 & $2687 / 282=$ & \\
\hline & $8,7-10,4$ & Cukup & 127 & 45,04 & 9,53 & \\
\hline & $10,5-12,2$ & Tinggi & 72 & 25,53 & & \\
\hline & $12,3-14,0$ & $\begin{array}{l}\text { Sangat } \\
\text { tinggi }\end{array}$ & 18 & 6,38 & & \\
\hline & & Jumlah & 282 & 100 & & \\
\hline Sub varaibel & $5,0-6,8$ & $\begin{array}{l}\text { Sangat } \\
\text { rendah }\end{array}$ & 28 & 9,93 & 9,93 & \\
\hline \multirow[t]{5}{*}{ Penanaman } & $6,9-8,6$ & Rendah & 64 & 22,70 & $2522 / 282=$ & $2522 / 282=$ \\
\hline & $8,7-10,4$ & Cukup & 124 & 43,97 & 8,94 & \\
\hline & $10,5-12,2$ & Tinggi & 55 & 19,50 & & \\
\hline & $12,3-14,0$ & $\begin{array}{l}\text { Sangat } \\
\text { tinggi }\end{array}$ & 11 & 3,90 & & \\
\hline & & & Jumlah & 282 & 100 & \\
\hline
\end{tabular}




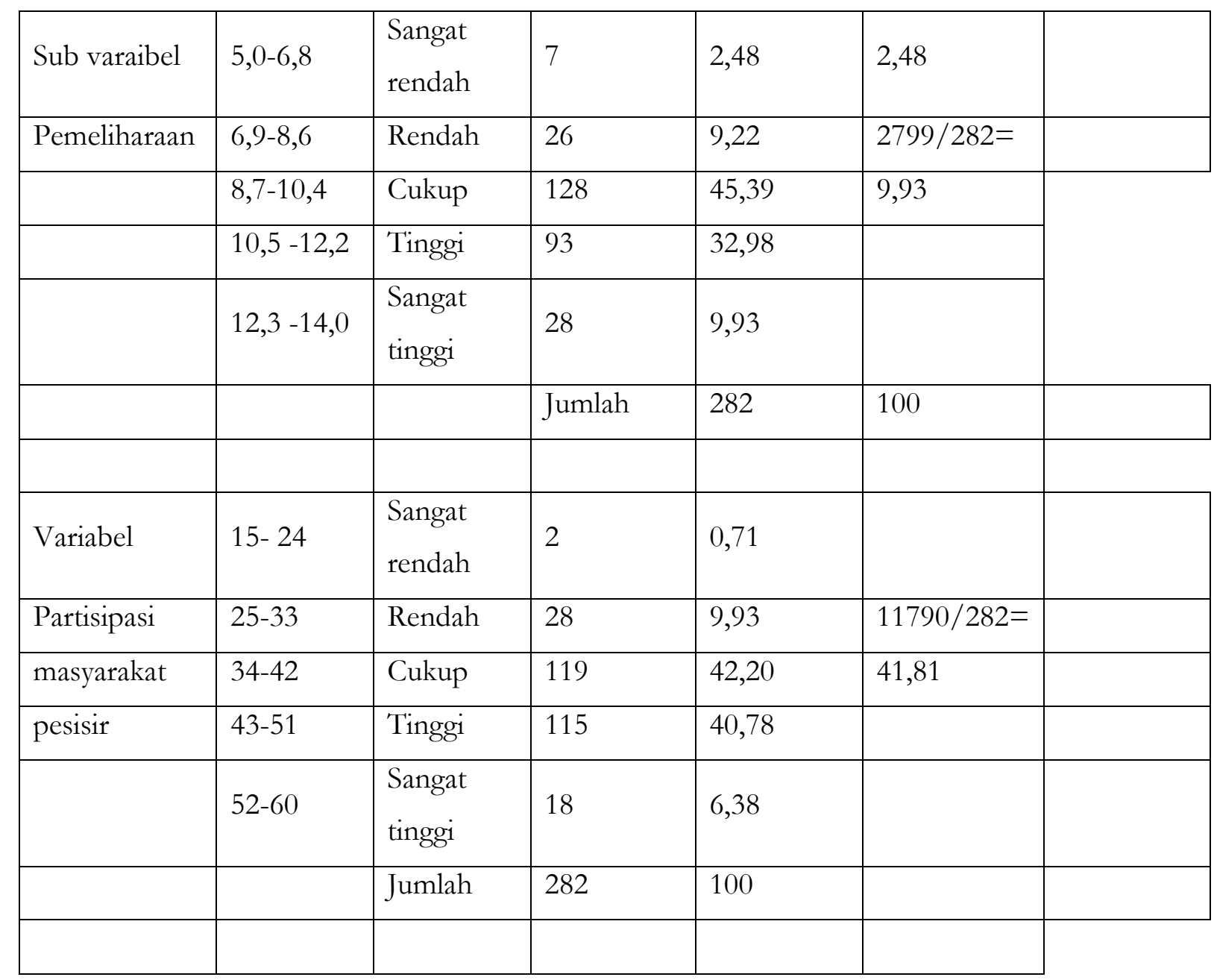

Sumber : DataPrimer diolah (2016)

Keempat, partisipasi masyarakat pesisir terhadap pemeliharaan tanaman mangrove cukup baik dengan memperoleh skor rata-rata 9,93. Untuk pertumbuhan dan perkembangan tanaman mangrove, perlu pemeliharaan dan perawatan sesuai baku teknis tanaman mangrove dibawah bimbingan teknis penyuluh agar tanaman dapat tumbuh dan berkembang dengan baik sehingga kelestarian pantai dapat tercapai. Masih ditemukan 2,48 \% responden yang sangat rendah partisipasinya terhadap pemeliharaan tanaman mangrove, hal ini masih tergolong wajar tetapi perlu didorong untuk ikut serta dalam partisipasi pemeliharaan tanaman mangrove yang sudah dikembangkan.

Kelima, partisipasi masyarakat pesisir yang terdiri dari indikator tersebut (perencanaan, pembibitan, penanaman, dan pemeliharaan) memperoleh skor rata-rata 41,81 termasuk katagori cukup. Artinya masyarakat pesisir sudah mulai peduli terhadap pengembangan tanaman mangrove. Mereka menganggap bahwa lingkungan pantai yang lestari akibat pengembangan tanaman mangrove merupakan keuntungan bagi kegiatan ekonomi, sehingga mereka menyadari betapa pentingnya menjaga kelestarian pantai. Masih ada $0,71 \%$ responden partisipasinya masih 
sangat rendah, oleh karena itu perlu dorongan, penyuluhan dan sosialisasi yang terus menerus agar mereka timbul kesadaran betapa pentingnya kelestarian lingkungan pantai untuk kegiatan ekonomi.

\section{KESIMPULAN}

1.Peranan pemerintah dalam pemberdayaan masyarakat pesisir memperoleh skor rata-rata 49,94 termasuk pada katagori cukup, artinya pemberdayaan masyarakat pesisir yang dilakukan oleh pemerintah melalui penyuluhan, sosialisasi, pembinaan dan studi banding termasuk dalam katagori cukup baik.

2.Peranan masyarakat pesisir melalui perencanaan, pembibitan, penanaman, dan pemeliharaan dalam pengembangan tanaman mangrove memperoleh skor rata-rata 41,81 termasuk katagori cukup, artinya masyarakat pesisir sudah mulai peduli terhadap pengembangan tanaman mangrove dalam pelestarian pantai. Karena mereka menganggap bahwa lingkungan pantai yang lestari merupakan keuntungan bagi kegiatan ekonomi, sehingga mereka menyadari betapa pentingnya pengembangan tanaman mangrove dalam menjaga kelestarian pantai.

\section{Daftar Pustaka}

Agustono, 1996. Nilai Ekonomi Hutan Mangrove Bagi Masyarakat (Studi kasus dimuara Cimanuk Indramayu ). Tesis PPs IPB, Bogor.

Anonimous, 2015. BPS. Kab. Pamekasan.. Pamekasan dalam Angka. Pamekasan Departemen Kehutanan Republik Indonesia. 2015.

Rahiem Fathor, 2005. Hubungan Kerapatan Mangrove dengan Jumlah Ikan di Kawasan

Mangrove Kecamatan Tlanakan Kabupaten Pamekasan Madura. Tesis Program Pascasarjana Unibraw, Malang.

Kusmana, C. 1995. Habitat Hutan Mangrove dan Biota. Laboratorium Ekologi Hutan. Fakultas Kehutanan. Bogor : Institut Pertanian Bogor.

Mulyana, Slamet. 1996. Peranserta Masyarakat dan Upaya Pengendalian Kerusakan Ekosistem

Kawasan Pesisir. Makalah disampaikan pada pelatihan penanganan pengendalian dan pengelolaan kawasan pesisir. Pantai dan laut. Pemda Tingkat I Jawa Tengah. Tanggal 21-26 Oktober 1996.

Nasir. 2003. Metode Penelitian. Ghalia Indonesia. Jakarta.

Nurmalasari, Y. 2001. Analisis Pengelolaan Wilayah Pesisr Berbasis Masyarakat. http://www.stmik- im.ac.id/userfiles/jurnal\%20yessi.pdf. Diakses tanggal 10 Februari 2013.

Parawansa, Indar. 2007. Pengembangan Kebijakan Pembangunan Daerah dalam Pengelolaan 
Hutan Mangrove di Teluk Jakarta secara Berkelanjutan. Disertasi. Sekolah Pascasarjana IPB. Bogor

Rasyid, Ryaas M. 1996. Makna Pemerintahan, Tinjauan dari segi Etika dan Kepemimpinan. Yasrif Watampua, Jakarta.

Santoso, Singgih. 2003. SPSS Versi 10. Mengolah Data Statistik Secara Profesional. Elex Media Komputindo. Jakarta.

Sugijono. 1999. Metode Penelitian Administrasi, Alfabeta. Bandung.

Suharsimi, Arikunto. 2006. Prosedur Penelitian Suatu Pendekatan Praktek. Rineka Cipta. Jakarta.

Sumodiningrat, G. 1999. Pemberdayaan Masyarakat dan Jaring Pengaman Sosial. Gramedia. Jakarta.

Supriyanto. 2004. Hubungan Pemberdayaan dan Partisipasi masyarakat dalam rehabilitasi Hutan Mangrove di Desa Jetis Kecamatan Nusawungu. Kabupaten Cilacap. Tesis. PP Undip. Semarang.

Sutrisno. 2015 Pemberdayaan dan Partisipasi Masyarakat Pesisir dalam Pengembangan Tanaman Mangrove di Kabupaten Pati. Jurnal Bina Praja | Volume 7 Nomor 1 Edisi Maret 2015

UU RI No 27 Tahun 2007 tentang Pengelolaan Wilayah

Pesisir dan Pulau-pulau Kecil.

Ummah, Y. C., \& Wajdi, M. B. N. (2016). Dismantling Paradigm Book Ta'limul Muta'allim. Educatio: Journal of Education, 1(2), 1-10. Retrieved from http://www.ejournal.staimnglawak.ac.id/index.php/educatio/article/view/26

Wajdi, M. B. N. (2016). HARMONISASI NILAI PENDIDIKAN ISLAM DENGAN KEARIFAN BUDAYA LOKAL. Jumal Studi Islam: Pancawahana, 11(1), 51-78. 